effect ${ }^{1}$ :- "I observed at table the under surface of a balf round of boiled salt beef, cooked the day before, to be specked with several bright carmine-coloured spots, as if the dish in which the meat was placed had contained minute portions of red currant jelly. Suspecting what these might turn out to be, I directed the beef to be placed aside. On examination the next day the spots had spread into patches of a vivid carmine-red stratum of two or more inches in length. With a simple lens the plant appears to consist of a gelatinous substratum of a paler red, bearing an upper layer of a vivid red hue, having an uneven or papillated surface. The microscope shows this stratum to consist of generally globose cells, immersed in, or connected by, mucilaginous or gelatinous matter. The cells vary in size, and contain red endochrome ; they seem to consist of a single cellmembrane, and contain a nucleus. Treated with sulpho-iodine they become blue."

As to its place in the organic kingdom, $\mathrm{Mr}$. Stephens was of opinion that it was a Palmella closely allied to Palmella cruenta, but distinct, the cells or granules of the latter differing from it, not only in their colour but size, being very much smaller than those of $P$. prodigiosa. As to its propagation, he further remarks that it seems to extend itself by elastically spurting a sort of jet or column of red particles, which Berkeley compared to a jet of blood from an artery, and by this method it was suggested that the extraordinary rapidity with which a large surface becomes covered can be explained. The vitality of the cells is not im. paired (within a certain time) by desiccation, even at a high temperature, and when dry they retain their germinating powers for a considerable period.

The spherical cells are filled with a reddish oil, which gives to them a peach-blossom tint, and when transferred to raw meat they assume a splendid fuch:ia-colour, resembling spots of blood. The plant is only developed in the dark, and the nitrogen necessary for its nutriment must be derived from the air, especially when developed upon bread. About 1886 an epidemic appearance on the Continent was attributed to this source. Pieces of cooked meat presented a singular carminered colouration, and stained vividly the fingers or linen with which they came in contact. These phenomena prevailed regularly for a period of three months. Food cooked over-night was found the next morning covered with red patches, and it then underwent rapid alteration. Coincident with a sudden and considerable fall in the temperature the epidemic ceased, and did not reappear. ${ }^{2}$

Fresenius records the result of his examination of this organism, in his "Beitrage," to the effect that "he took four boiled potatoes, and placed them in a drawer, having previously rubbed twn of them slightly here and there with the red sub. stance. After about twenty-four hours, the two potatoes which had not been rubbed, and which had not been in immediate contact with the other two, were affected with fresh spots of the red substance, whilst the spots upon the two which had been rubbed had increased in extent. The spots showed themselves in the form of irregular groups of blood-red drops of different size, which in some places were distinct, and in others had run into one another. The individual bodies of which the spots consist are mere molecules, their diameter varying from one twothousandth to one four-thousandth of a line. They are mostly round, occasionally oval, and sometimes slightly constructed in the middle, by way of preparation for increase by division into two small round cells. By far the greater number of them, when brought under the microscope in a drop of water, remain at resl-they lie close together in large numbers ; when they are more dispersed in the fluid they have a motion which is not distinguishable from ordinary molecular motion. When the drop of water moves they are carried mechanically over the stage like other molecules, and when this motion ceases they remain at one spot in a sort of quivering state until a fresh current carries them in another direction. If the eye be kept carefully upon a part of the stage where the small bodies are thinly dispersed, it will be observed that they passively follow the current of the water, nor, when the current has become sluggish, or has even allogether ceased, are individual bodies ever seen to detach themselves from the group, and take a contrary direction, which real monads would do with great activity."

The present determination of this organism, according to some, is Micrococcus prodigiosus, but according to others it is

1 H. O. Stephens, on Palmella prodigiosa in Annals of Nat. Hist. vol. xii. December, 1853

Pharmaceutical Gournal, January 29, 1887, p. 6ro.
Bacillus prodigiosus, and consequently one of the Schizomycetss. It has been pointed out that as the te.nperature rises this Bacillus loses its power of forming a pigment, and if it is grown on potato or bread-paste, in an incubator at blood heat, instead of at the temperature of the room, the colour is gradually lost, and the culture no longer smells of herring brine, but the power of forming lactic acid from milk-sugar, with the accompanying precipitation of the casein, is frequently considerably increased; so that it would appear that the energy required for the build. ing-up of the pigment substance was, in this case, diverted into another channel, and lactic acid, and perhaps other substances, are produced in place of the usual pigment. ${ }^{1}$

The reappearance of this organism in this country, during the late hot weather, and especially on cooked potatoes, gives interest to its history, and is sufficient apology for these observations. M. C. Cooke.

\section{FORTHCOMING SCIENTIFIC BOOKS}

THE autumn publishing season has opened with announce. ments of forthcoming books to suit all requirements. From this year's list we see that many works of high scientific importance are in the press, but the chief feature is the large number of text-books announced. The work of the Technical Instruction Committees of our County Councils has naturally resulted in the preparation of books on various arts and handi. crafts, and since the authors of these books are usually well versed in the technicalities of their subjects, it may be presumed that the 'prentice hand will derive benefit from their literary efforts.

The following books are announced by Messrs. MaCmiLla N AND Co:-The Collected Works of Thomas Henry Huxley, F.R.S., in monthly volumes, from October I. Vol. i. "Methods and Results" (just published) ; vol. ii. "Darwiniana" Vol. iii. "Science and Education"; vol. iv. "Science and Hebrew Tradition"; vol. v. "Science and Christian Tradi. tion"; Vol. vi. "Hume." "Systemalic Survey of the Organic Matters," by Drs. G. Schultz and P. Julius, translated and edited, with extensive additions, by Arthur G. Green, Examiner in Coal Tar Products to the City and Guilds of London Institute. "Text-Book of the Diseases of Trees," by Prof. R. Hartig, translated by Dr. R. S.omerville, Lecturer on Agricul. ture at Durham College of Science, with a preface by Prof. $H$. Marshall Ward, F.R.S., with numerous illustrations, "Methods of Histological Research," for the use of students and physicians, by I;r. C. V. Kahlden, Lecturer in the University of Freiburg, translated by H. Morley Fletcher. "Materials fur the Study of Variation in Animals." Part i. "Discontinuous Variation," by William Bateson, Balfour Student and Fellow of St. John's College, Cambridge, illustrated. "Handbook of British Marine Fauna," vol. i. Tunicata, Polyzox, and Echinodermata, by Prof. W. A. Herdman, F.R.S., wiih numerous illustrations. "The Romance of the Insect World," by Miss L. N. Badenoch, with illustrations. "A Text-Book of Pathology," syste. matic and practical, by Prof. D. J. Hamilton, vol. ii." "Handbook of Public Health and Demography," by Edward F. Willoughby, Diploma in Sta'e Medicine of the London University, and in Public Healıh of Cambridge University. "The Practitioner," an index to vols. I-50 of the Practitioner, a journal of therapeutics and public health. The three following volumes have been designed to suit the requirements of the examinations of the Department of Science and Art :- "Organic Chemistry for Beginners," by Dr. G. S. Turpin ; "Physiography for Beginners," by J. E. Marr, F.R.S., and Alfred Harker, M.A. ; "Physiology for Beginners," by Prof. Michael Foster, F.R.S., and Dr. L. E. Shore. "Geometrical Conic Sections," by Charles Smith. "Geometrical Conic Sections," by Asutosh Mukhopadhyay, Fellow of the University of Calcutta. "Geo. met ical Conics," Part ii., the Central Conic, by John J. Milne and R. F. Davies. "Elementary Trigonometry," by H. S. Hall, Master of the Army Class, Clifion College, and S. R. Knight. "Sketches in Sport and Natural History," by the late Dr. George Kingsley; "The Beauties of Nature," by the Right Hon. Sir John Lubbock, Bart., F.R.S., new edition without illustrations; "The Theory of Heat," by Thomas Preston, with illustrations; "Researches on the Propagation of Electrical Force," by Prof. Heinrich Hertz, of Bonn, authorised translation by Prof. D. E. Jones, with preface by Lord Kelvin, P.R.S.,

NO. I 25 O, vOL. 48 ] 
illustrated; "A Text-book on Electro-Magnetism and the Construction of Dynamos," by Dugald C. Jackson, Professor of Electrical Engineering, University of Wisconsin; "The Mechanics of Hoisting Machinery, including Accumulators, Excavators, a) d Pile Drivers," by Dr. Julius Weisbach and Prof. Gustav Hermann, with 177 illustrations, authorised translation from the second German edition, by Karl P. Dahlstrom, Instructor in Mechanical Engineering at the Lehigh University; "Hydrostatics," by A. G. Greenhill, F.R.S., Professor of Mathematics to the Senior Class of Artillery Officers, Woolwich ; "Essays in Historical Chemistry," by Prof. T. E. Thorpe, F. R.S.. ; "The Rise and Development of Organic Chemistry," by the late C. Schorlemmer, F.R.S., tran:lated and edited by Prof. Smithells, Yorkshire College, Leeds ; "Popular Lectures and Addresses," Vol, ii., contributions to Geology, by Lord Kelvin, P.R.S.; "The Life of Sir A. C. Ramsay," by Sir Archibald Gerkie, F.R.S. ; "A Text-book of the Physiological Chemistry of the Animal Body, including an Account of the Chemical Changes occurring in Disease," by Dr. Arthur Gamgee, F.R.S., Brackenbury Professor of Physiology in the Owens College, with illustrations, Vol. ii. ; "Boot and Shoe Manufacture," by C. W. B. Burdett, Head Master City and Guilds of London Leather Trade Schools, with numerous illustrations; "Lead Work," by W. R. Lethaby, with illustrations ; "Gold-Milling," with illustrations, by H. Louis; "Elementary Course of Practical Science," by Hugh Gordon.

The CAMBRIDGe UNIVERSITY Press announce:- "The Scientific Papers of John Couch Adams," Vol, i., edited by Dr. William Grylls Adams, F.R.S., \&c., Professor of Natural Philosophy in King's College, London, late Fellow of St. John's College, Cambridge, with a memoir by Dr. J. W. L. Glaisher, F.R.S., \&c., Fellow of Trinity College, Cambridge; "A Treatise on Spherical Astronomy," by Sir Robert S. Bail, F. K.S., Lowndean Professor of Astronomy and Geometry ; "A Treatise on the Theory of Functions of a Complex Variable," by Dr. A. R. Forsyth, F.R.S., Fellow of Trinity College, Cambridge; "Plane Trigonometry," hy S. L. Loney, Part i., up to and including the Solution of Triangles, is published separ. ately; "Solutions of the Examples in a Treatise on the Elements of Stalics and Dynamics," by S. L. Loney, late Fellow of Sidney Sussex College, Cambridge: "Elementary Hydrosłatics," by John Greaves, Fellow and Lecturer of Christ's College ; "The Steam Engine and other Heat Engines," by I. A. Ewing, F.R.S., Prufe sor of Mechanism and Applied Mechanics in the University of Cambridge ; "Elementary Palæontology for Geological Students," by Henry Woods "Practical Physiology of Plauts," by F. Darwin and E. H. Acton. Pitt Press Mathematical Series:- "Euclid's Elemients of Geometry," Books v. and vi, by H. M. Taylor, Fellow and formerly Tutor of 'Trinity College, Cambridge; "Solution: to the Exercises in Euclid," Books i iv. (Pitt Press Malhematical Series, by H. M. Taylor), by W. W. Taylor. The Cambridge University Press are also about to publish a series of Natural Science Manuals, which will cover a wide field, some of the books being adapted for beginners, wbilst others will deal with special topics, and will be useful only to more advanced students. The series will be divided into two sections, a Biological and a Physical. The former will be published under the general editorship of Mr. Arthur E. Shipley, Fellow and Tutor of Christ's College, Cambridge; it will include "A Manual of Invertebrate Palæontology," by Mr. H. Woods, Demonstrator of Palæobotany at Cambridge, which is now ready; "A Text-book on the Practical Physiology of Plants," by Mr. Francis Darwin, of Christ's College, and Mr. E. Hamilton Atton, of St. John's College, which is in the press ; "Works on Physical Anthropology," by Prof. Alexander Macalister ; "On the Vertebrate Skeleton," by Mr S. H. Reynolds, of Trinity College; "On Fossil Plants," by Mr. A. C. Seward, Lecturer in Botany in the University, and "An Intioduction to the Study of Botany," by Mr. Francis Darwin, which are in preparation. Other volumes will shortly be announced. The volumes of the Physical Series already arraıtged for include three by Mr. R. T. Glazebrook, F.R.S., Assistant-Director of the Cavendish Laboratory, on "Light and Heat," "Electricity and Maynetism," and "Mechanics and Hyctrostatics"; these will be elementary text-books, based on the Practical Courses of Physics fur Medical Students at the Cavendish Laboratory. The volume on "Light and Heat" is in the press, and the other volumes are in preparation.

Messrs. Charles Griffin and Co.'s announcements in- clude :- "A Text-book of Ore and Stone Mining for the Use of Mine-owners, Mine-managers, Prospectors, and all interested in Ore and Stone Mining," by Dr. Clement Le Neve Foster, F.R.S., Professor of Mining, Royal College of Science, H.M. Inspector of Mines; a new Metallurgical series, edited by W. C. Roberts-Austen, C. B., F.R.S., Chemist and Assayer of the Royal Mint, Professor of Metallurgy in the Royal College of Science. (I) "Introduction to the Study of Metallurgy," by the Editor ; third edition. (2) "Gold (The Metallurgy of)," by Thos. Kirke Rose ; (3) "Copper (The Metallurgy of)," by Thos. Gibb; (4) "Iron and Steel (The Metal. lurgy of)," by Thos. Turner; (5) "Metallurgical Machinery: the Application of Engineering to Metallurgical Problems," by Henry Charles Jenkins ; (6) "Alloys," by the Editor. Technological Manuals: "Oils, Fats, Waxes, and Allied Materials, and the Manufacture therefrom of Candles, Soaps, and other Products," by Dr. C. R. Alder Wright, F.R.S.; "Agricultural Chemistry and Analysis : A Practical Handbook for the Use of Agricultural Students," by Dr. J. M. H. Munro, Professor of Chemistry, Downton College of Agriculture; "Dairy Chemistry: A Practical Handbook for Dairy Managers," by H. Droop Rich. mond; "Cements: A Practical Handbook on their Manufacture, Properties, Testing," \&c., by Gilbert R. Redgrave ; "Petroleum : A Treatise on the Geographical Distribution, Geological Occurrence, Chemistry, Production, and Refining of Petroleum; its Testing, Transport, and Storage; and the Legislative Enactments relating thereto; together with a Description of the Shale Oil Industry," by Boverton Redwood, assisted by Geo. T. Holloway. With maps and illustrations. The special features of Mr. Redwood's work will be (I) the hitherto unpublished descriptions of undeveloped sources of petroleum in various parts of the world; and (2) that the testing, transport, and storage from the point of view of legislation, and the precautions which experience in this and other countries has shown to be necessary in the interests of public safety. "A Text-book of Physics : including Properties of Matter, Heat, Sound and Light, Magnetism and Electricity," hy Dr. J. H. Poynting, F.R.S., late Fell. of Trinity Cull., Cambridge; Prof. of Physics in the Mason Coll., Birmingham, and J.J. Thomson, F.R.S., Fell. of Trinity Coll., Cambridge; Prof. of Exper. Physics in the Univer. of Camb. ; "The Mean Density of the Earth: An Essay to which the Adams Prize was adjudged in 1893 in the University of Cambridge," hy Dr. J. H. Poynting, F.R.S., in large $8 \mathrm{vo}$, with bibliography, illustrations in the text, and lithographed plates; "Marine Engineering Rules and Tables (A Pocket-book of): for the use of Marine Engineers, Naval Architects, Designers, Draughtsmen, Super. intendents, and all engaged in the design and construction of Marine Machinery, Naval and Mercantile," by A. E. Seaton and H. M. Rounthwaite, with illustrations; "Gas, Oil, and Air Engines: A Practical Text-book on Internal Combustion Motors without Boiler," by Bryan Donkin, with illustrations ; "Sewage Disposal Works," by W. Santo Crimp. Second edition, with additional plates; "Engineering Drawing and Design: A Practical Manual for Engineering Students," by Sidney H. Wells, Principal, Battersea Polytechnic Institute, late of Dulwich College. Part I.-Geometry : Practical, Plane, and Solid. Part II.--Machine and Engine Drawing and Design. Complete in one vol., with numerous illustrations and folding-plate; "Applied Mechanics (An Advanced Text-book of)," by Prof. Jamieson, Glasgow and West of Scotland Technical College, with very numerous illustrations.

Messis. SWAN, SONNENSCHEIN AND Co.'s forthcoming works are chiefly text-books. We note :- "A Student's Textbook on Botany," by Dr. Sidney H. Vines, Professor of Botany, in the University of Oxford, editor of "Prantl's Botany," copiously illustrated ; "Text-book of Embryology, Invertebrates," by Drs. Korschelt and Heider, of the University of Berlin, translated and edited by Dr. E. L. Mark, Professor of Anatomy in Harvard University, and Dr. W. M. Woodworth, Instructor in Microscopical Anatomy in Harvard University, Part I., illustrated ; "The Cell, its Anatomy and Physiology," by Dr. Oscar Hertwig, of the University of Berlin, translated and edited by Dr. H. J. Campbell, illustrated; "Text-book of Palæontology for Zoological Students," by Theodore T. Groom, illustrated ; "Lectures on Human and Animal Psychology," by Wilhelm Wundt, Professor of Philosophy in the University of Leipzig, translated and edited by James Edward Creighton, Instructor in Philosophy to the Cornell University, lthaca,

NO. I 25 O. YroL. 487 
New York, and Elward Bradford Titchener, of the Cornell University; "Hındbook of Systematic Botany," by Dr. E. Warming, Professor of Botany in the University of Siockholm, translated and edited by M. C. Potter, M.A., Lecturer on Biolosy and Botany in the Durham College of Science, illustrated ; "Town Flowers," by J. W. N., with a preface by Canon Benham and Prebendary Wesb-Peploe ; "Zoology," by B. Lindsay, illustrated; "Fishes," by the Rev. H. A. Mac. pherson ; "Flowering Plants," by James Britten, editor of the Journal of Eotany; "Grasses," by W. Hutchinson; "Mammalia," by the Rev. H. A. Macpherson; "The Natural History and Antiquities of Selborne," by Gilbert White, Bennett's edition, with notes by J. E. Harting, illustrations by Bewick, Harvey, \&c., new edition.

Messrs. CROSBY LOCKWOOD AND Sons have in preparation and in the press. - "Machinery for Metalliferous Mines: a Practical Treatise for Mining Engineers, Metallurgists, and Managers of Mines," by E. Henry Davies (illustrated); "The Practical Engineer's Year-book for I894, comprising Modern Engineering Formulæ, Rules, Tables, and Memoranda, in Civil, Mechanical, Electrical, Marine, and Mine Engineering," by $\mathrm{H}$. R. Kempe ; "Practical Building Construction: a Hiandbook for Students Preparing for the Examinations of the Science and Art Department, the Royal Institute of British Architects, the Surveyors' Institution, \&c., designed also as a Book of Reference for Persons engaged in Building" (I000 illustrations), by John Parnell Allen; "Concrete: Its Nature and Uses: a Book for Architects, Builders, and Clerks of Works" (with numerous illustrations), by George L. Sutcliffe ; "Tramways : Their Construction and Working, embracing a Comprehensive History of the System; with an exhaustive Analysis of the various Modes of Traction, a description of Rolling Stock, and details of Cost and Working Expenses" (with plates and other illustrations), by D. K. Clark. new edition, in one volume, rewritten and revised; New Volumes of Hasluck's Series of "Handybooks for Handicrafts," viz. : "The Woodworker's Handybook: a Practical Manual on the Tools, M.tterials, Appliances and Processes employed in Woodworking" (with Ioo illustrations); "The Metalworker's Hundybogk: a Practical Manual for use in Technical Classes and Workshops" (with 100 illustrations); "Wall Paper Ducoration" (with numerous illustrations), by A. S. Jennings; "An Astronomical Glossary; or Dictionary of Terms used in Astronomy, with Tables of Data and Lists of Remarkable and Interesting Celestial Objects," by J. Ellard Gore.

Messrs. Cassell AND Co. promise the following books:"The Story of the Sun," by Sir Robert S. Ball, F.R.S., Lowndean Professor of Astronomy in the University of Cambridge, about 380 pages, with 8 coloured plates and other illustrations; "The Story of our Planet," by T. G. Bonney, F.R.S., Professor of Geology in University College, London, Fellow of St. John's College, Cambridge, with 6 coloured plates and maps and about Joo illustrations; "The Dawn of Astronomy, a Study of the Astronomy and Temple Worship of the Ancient Egyptians," by J. Norman Lockyer, F.R.S. ; "Our Railways, their Development, Enterprise, Incident, and Romance," by John Pendleton, illustrated ; "Electricity in the Service of Man, a Popular and Practical Treatise on the Applications of Electricity in Modern Life," with nearly 850 illustrations, new edition, revised by $\mathrm{Dr}$. R. Mullineux Walmsley; "Cassell's New Technical Educator," an entirely new Cyclo. pædia of Technical Education," with coloured plates and engravings, Vol. ii. ; "The Book of the Horse," by S. Sidney, thoroughly revised and brought up to date by James Sinclair and W. C. A. Blew, with 17 full-page collotype plates of celebrated horses of the day, specially produced for this edition, and numerous other illustrations.

The following are included in Messrs. GEORGE PHILIP AND Son's list of forthcoming publications:- "The Mineral Resources of Western Australia, with full descriptions of the Goldfields," by Alfred F. Calvert; "Philips" Anatomical Model," a Pictorial Representation of the Human Frame and its Organs by means of superimposed Plates printed in colours, with descriptive text by Dr. Schmidt, English edition by William S. Furneaux; “Philips' Geological Map of the Environs of London, extending about twenty miles round Charing Cross, showing the Nature of the Soil and the Elevation of the Land," by George Philip (scale, one inch to a mile); "Lessons on Woodwork for Evening Classes, comprising Exercises in the Principles of Joinery, and Studies and Designs for Wood-Carving," with numerous illustrations and explanatory letter-press ; published under the direction of the Technical Education of the Hants County Council.

In addition to a number of books of travel, Mesirs. SAMP. SON Low, MARSTON AND Co.'s publications will be:-- "A History of Scandinavian Fishes," described by B. Fries, C. Y. Ekström, and C. Sundeval!, with coloured plates painted from living specimens, and engraved on stone by Wilhelm von Wright, besides numerous text illustrations, second edition, thoroughly revised and completed by Prof. F. A. Smitt ; "A School Course in Heat," revised and enlarged, by W. Larden, Assistant Master in the R.N.E. College, D:vo rpor:, late Science Scholar, Merton College, Oxford, numerous illustra. tions, fifth edition; "Chemistry for Beginners," adapted for Elementary Stage of the Science and Art Department's Examinations in Organic Chemistry, by R. L. Taylor, fifth edition, thorougbly revised and parlly rewritten.

Messrs. Chapman and Hall have in hand:- "About Orchids: a Chat," by Frederick Boyle, with numerous illus. trations; a book by Mr. Charles Dixon, entitled "Jottings ab ut Birds"; "Woodworking Positions," hy W. Nelson, with twelve illustrations by Heroert Cole; "A Text-book of Mechanical Engineering," by Wilfrid J. Lineham, Head of the Engineering Dipartment at the Goldsmiths' Company's Institute, New Cross, late Professor of Engineering at the Schrol of Science and Art and Technical College, Newcastle-on. Tyne; "Illustrations of the Principal Natural Orders of the Vegetable Kingdom," prepared for the Sience and Art Department, by Dr. D. Oliver, F.R.S., with 109 plates by W. H. Fitch ; "Food, some Account of its Sources, Constituents, and Uses," by A. H. Church, F.R.S., Professor of Chemistry in the Royal Academy of Arts in London, new edition, revised.

The following works will be published by Mr. Young J. PENTLAND :- "Atlas of Diseases of the Skin, in a Series of Coloured Illustrations from Original Drawings, with Descriplive Lelterpress," by Dr. H. Radcliffe Crocker; "Manual of Practical Anatomy," by Dr. D. J. Cunningham, Professor of Anatomy and Surgery, Trinity College, Dublin; "Hygiene and Diseases of Warm Climates, in a Series of Articles by Eminent Authorities," edited by Dr. Andrew Davidson, author of "Geographical Pathology," illustrated; "Buri-Beri, Researches concerning its Nature and Cause, and the Means of its Arrest," by C. A. Pekelharing, Professor in the Faculty of Medicine, University of Utrecht, and C. Winkler, Lecturer in the University of Utrecht, translated by James Cantlie ; "Atlas of Ophthalmoscopy, a Series of Coloured Plates from Oiginal Drawings, with Text," by W. Adams Frost.

Mr. W. B. Clive (University Correspondence Press) will publish :- "Elementary Qualitative Analysis," by William Briggs and Dr. R. W. Stewart; "An Elementary Textbook of Geometrical Conics," by G. H. Bryan; "Geometrical Deductions," by T. W. Edmondion; "Geometry of the Simpler Figures and the Plane, Euclid VI. and XI.," by C. W. C. Barlow; "An Elementary Text-book of Hydro" statics," by William Briggs and G. H. Bryan; "Examples in Magnetism and Electricity," by C. H. Dibb; "An Elementary Text-book of Mechanics," by William Briggs and G. H. Bryan; "The Elements of Trigonometry," by William Briggs and G. H. Bryan; "Co-ordinate Geometry, Part II.," by G. H. Bryan.

In Mr. MurRay's list of forthcoming books we find :- "The Life of Prof. Owen, based on his Correspondence, his Diaries, and those of his Wife," by his grandson, the R $\vec{v}$. Richard Owen, with portraits and illustrations. 2 vols. "A Manual of Naval Architecture, for the Use of Officers of the Navy and Mercantile Marine, Ship-owners, Ship-builders, and Yachts. men," by W. H. White, C.B., F.R.S., Assistant-Controller and Director of Naval Construction, Royal Navy. Third edition thoroughly revised and in great part rewritten, with I 50 illustrations.

The announcements of the CLARENDON PRESS include " $\mathrm{Ma}$. thematical Papers of the late Henry F. S. Smith," Savilian Professor of Geometry in the University of Oxfurd, with portrait and memoir, 2 vols.; "A Manual of Crystallography," by $\dot{M}$. H. N. Story-Maskelyne, F.R.S. ; "Observations on some Points connected with Hospital Construction," by Sir D ruglas Galton, K.C.B. F.R.S.; "A Monograph on the Oligochæla," by Frank E. Beddard, F.R.S. ; "Adler's Alternating Generations,

NO. I 250 , vOI.. 48 ] 
a Biological Study of Oakgalls and Gallfies." authorised translation, by C. R. Straton.

Messrs. Longmans, Green and Co. have in preparation :"Agricultural Analysis, a Manual of Quantitative Analysis for Students of Agriculture," by Frank T. Addyman; "The Outdoor World, or the Young Collector's Handbook," by W. Furneaux, with 546 illustrations, including 16 coloured plates; "Eskimo Life," by Fridtiof Nansen, author of "The First Crossing of Greenland," translated by William Archer, with illustrations.

Camille Flammarion's "Popular Astronomy " is being trans. lated by Mr. J. Ellard Gore, and will be published by Messrs. Chatro and Windus. This firm will also publish "The Sagacity and Morality of Plants: a Sketch of the Life and Conduct of the Vegetable Kingdom," with coloured frontispiece and 100 illustrations; "Our Common British Fossils, and Where to Find Them, a Handbook for Students," with $33 \mathbf{I}$ illustrations; "The Playtime Naturalist," with 366 illustrations.

The volumes on scientific subjects announced by Messrs. Rivington, Percival and Co. are:- "The School Euclid," by Mr. Daniel Brent ; "The Begirner's Text-Books of Science": "Chemistry," and "Heat," by Mr. G. Stallard ; "Geology" and "Physical Geography," by Mr. C. L. Barnes ; "Electricity and Magnetism" and "Mechanics (Treated Experimentally)," by Mr. L. Cumming; "Light," by Mr. H. P. Highton; "Practical Physics," in three parts, by Prof. W. F. Barrett ; "Practical Lessons and Exercises in Heat," by Mr. A. D. Hall.

In the list of books about to be published by Messrs. W. H. AlLEN AND Co. we find:- " The Naturalist's Library," each section rewritten by well known naturalists, edited by Dr. R. Bowdler Sharpe, in 20 vuls.; "Handtook of British Hepaticæ, containing Descriptions and Figures of the Indigenous Species of Marchantia, Jungermannia, Riccia, and Anthoceros," by Dr. M. C. Cooke, author of "A Manual of Structural Botany," \&c. ; "The Flowering Plants of Western India," by the Rev. Alexander Kyd Nairne.

Messrs. KEGAN PAUL AND Co. announce a new volume of "Modern Science Series": "The Fauna of the Deep Sea," by Sydney J. Hickson, Downing College, Cambridge (with illustrations); also a new volume of the "International Scientific Series: "The Dispersal of Shells: an Inquiry into the Means of Dispersal possessed by Fresh-water and Land Mollusca," by H. Wallis Kew, with a Preface by Dr. Alfred Russel Wallace, F.R.S., \&c. (with illustrations).

Messrs. GEORGE BELL AND SONS propose to issue Vol. iii. of the "British Fungus-Flora, a Classified Text-book of Mycology," by George Massee, author of "The Plant World," with numerous illustrations; "The Elements of Applied Mathematics, including Kinetics, Statics, and Hydrostatics," by C. M. Jessop: "Elementary Analytical Geometry," by the Rev. T. G. Vyvyan.

Messrs. FREDERICK WARNE AND Co. announce:--"The Royal Natural History," edited by Richard Lydekker, with pre. face by P. L. Sclater, illustrated with seventy-two coloured plates, and upwards of sixteen hundred wood engravings, by W. Kuhnert, J. Wolf, T. Specht, Gambier Bolton, P. I. Smit, \&c., to be issued in monthly parts, beginning this month.

Messrs. Methuen and Co. will add to their University Extension Series a popular introduction to modern physical astronomy, entitled "The Vault of Heaven," by R. A. Gregory; and "Meteorology; the Elements of Weather and Climate," by Mr. H. N. Dickson.

From Messrs. A. ANI C. BLACK will come "Investigations in Microscopic Foams and on Protoplasm," by Prof. O. Biitschli, translated from the German by E. A. Minchin, illustrated ; and the remaining two parts of Prof. Newton's "Dictionary of Birds."

The following are among the educational announcements of Messrs. BlaCkIE AND SON :- "Text-book of Heat," by Dr. C. H. Draper; " Students' Introductory Handbook of Systematic Botany," by J. W. Oliver; "Elementary Hydrostatics and Pneumatics," by R. Pinkerton.

Messrs. W. AND R. CHAMbers will add to their list :"Electricity and Magneti-m," by Prof. Cargill G. Knott ; " Organic Chemistry," by Prof. Perkin; " Elementary Science," by S. R. Todd ; "Navigation," by J. Don.

Among Messrs. WILliams AND Norgate's forthcoming books is "A Pocket Flora of the Edinburgh District," by C. $O$.

$$
\text { NO. } 1250 \text { VOL. } 48 \text { ] }
$$

Sonntag, of the Edinburgh High School, with an Analytical Key to Orders and Genera.

Messrs. J. Hughes AND Co. announce "Horours Physio. graphy," by R. A. Gregory and H. G. Wells, and a second edition of Prof. Walker Overend's "Elements of Physiology."

The Religious Tract Society announce "The Romance of Electricity," by John Munro, with illustrations.

\section{TRILOBITES WITH ANTENN'A AT LAST!}

$\mathrm{M}$ R. W. D. MATTHEW ${ }^{1}$ is to be warmly congratulated on being the first to describe Trilobites with visible antenna. His detailed and illustrated description of a rich find (some sixty specimens) of Triarthrus Beckii with antennæ, made by Mr. Valiant in the Hudson River shales near Rome, N.Y., must naturally cause excitement among biologists all over the world.

The complete absence of all traces of visible antennæ, and, further, the failure of Waicott, after the most patient research by means of sections, to discover any antennal system at all, have resulted in the Trilobites remaining without abiding home in the zoological system. They have been Isopods, Phyllopods, and even Arachnida. And now, at last, Trilobites have been found with very pronounced antennæ! The first question we naturally ask is, what light do these antenræ throw upon the affinities of this mysterious group?

According to the description, these organs are long, manyjointed, typical crustacean antenræ. "They come out close together from just under the centre of the anterior border of the head shield." . . . "Their point of origin seems to be under the front part of the glabella, as they can be traced a little way under the head shield, where they almost coalesce, then turn upwards and outwards and disappear." ... "Iust over the spot where they come out, the anterior margin of the head shield is arched slightly upwards, seemingly to give room for them to play to and fro."

Frum these details we deduce the following :-

(I) All Trilobites had antennæ, which except, as far as we know, in the ease of Triarthrus Beckii alone remained shut in under the head shield.

(2) These ventrally placed antennæe were inserted, approxi mately, one on each side of the labrum.

It seems to me that these natural conclusions from the facts go far to establish the relationship between the Trilobites and the Apodida originally maintained by Burmeister, and recently elaborated by the present writer ("The Apodidæ," "Nature Series," I892). But however weighty the arguments (amounting, it seemed to me, to a proof) in favour of this relationship, the inability actually to demonstrate the existence of the antennæ was a felt weakness. That weakness has now been finally removed, and my arguments have been fully confirmed, by the finding that the Trilobites had antennæe in practically the same position as the antericr pair in the A podidæ.

The Trilobites may therefore take a firm place at the rout of the Crustacean system, with the existing Apus as their nearest ally.

The modern Crustacea, with their two pairs of antennæ arranged in a group with the eyes at the most anterior end of the body, have then to be deduced from primitive forms in which the antenne were placed ventrally at the sides of the labrum, and were shut in under a large head shield. Triarthrus Becki $i$ shows us one attempt to bring the antennæ forward. A pair of antennæ (presumably the anterior pair) lengthened considerably, and, without apparently changing their places of insertion, projected from under the head shield through a median groove. In spite of this actual discovery, I still think that the method of attaining the same end proposed by me (loc. cit.) was the method finally adopted. I suggested two grooves, one on each side of the median line, along which the antennæ moved bodily to the front. This would allow both pairs to act as anterior feelers, whereas the method adopted by Triarthrus would apparently only allow one pair to do so. Further, the piece between the grooves would account for the rostrum, which we know was very early developed. The antennze in the early Phyllopod Cerativcaris papilio were not long and filiform as in the Trilobite Triarthrus, but look exactly like a pair of Apus antenna: moved bodily to the front.

Whether the remarliable resemblance of the Isopods to the

I "On the Antennæ and other Appendages of Triarthrus Beckii." (American foumal of icience, August, 1893.) 